\title{
SURGICAL MANAGEMENT OF STAGE III THYMIC TUMORS
}

\author{
EVRE III TIMIK TÜMÖRLERE CERRAHI YAKLAŞIM
}

\author{
Federico Venuta, Giulia Macrì, Marco Anile, Daniele Diso, Emanuele Russo, Miriam Patella, \\ Domenico Vitolo, Erino A Rendina \\ Università di Roma Sapienza Fondazione Eleonora Lorillard Spencer Cenci \\ e-mail: federico.venuta@uniroma1.it \\ doi:10.5152/tcb.2012.12
}

\begin{abstract}
In this report, we will be discussing the advanced phase, stage III of thymoma, which are the most frequently seen mediastinal tumors in adults, and thymic carcinoma. Stage III thymic tumors represent an advanced stage of disease with involvement of the pericardium, great vessels, phrenic nerves, lung parenchyma and chest wall. Nowadays, complete resection is the gold standard in the treatment of thymic tumors. However, a selected group of patients should receive neoadjuvant chemotherapy to improve the outcome when the preoperative work up demonstrates that the tumor is considered potentially unresectable. Surgical procedures include median sternotomy, clamshell incision and an inverse $\mathrm{T}$ approach. Each procedure has its own advantages and disadvantages. Stage III thymic neoplasms are often a real surgical challenge and in many cases neoadjuvant treatment should be considered. However, if complete surgical resection could be achieved even in stage III, survival rates can reach similar survival rates to the patients with stage I and II tumors. Resection of the right atrium and pericardium, left brachiocephalic vein, lung and diaphragm can be per formed. Complete resection can be obtained by the reconstruction of the ascending aorta and main pulmonary artery or the resection of one phrenic nerve. Invasion of the myocardium is a clear sign of unresectability. Synthetic materials such as polytetrafluoroethylene-PTFEgrafts or bovine pericardium are used frequently for SVC reconstruction. Notwithstanding this aggressive multimodality approach, 5-year-local and distant recurrences are still present; 5-year survival rates range from $46 \%$ to $88 \%$; at 10 year the range is from $26 \%$ to $84 \%$. Adjuvant treatment after complete resection needs validation through prospective randomized trials, except in the case of incomplete resection or simple debulking where this therapy is clearly recommended.
\end{abstract}

Key words: Stage III thymic tumors, surgical management

\section{Özet}

Bu yazıda erişkinlerin en sık görülen mediastinal tümörü olan timoma ve timik karsinomda lokal ileri evre hastalık, evre III tartışılacaktır. Timik tümörlerde evre III perikard, büyük damarlar, frenik sinirler, akciğer parankimi ve göğüs duvar gibi komşu yapıların tutulumunu içeren ileri evre hastalığı tarif eder. Timik tümörlerde günümüzde tedavinin altın standartı tam rezeksiyondur. Ancak eğer preoperatif değerlendirilme sonrasında tümör potansiyel olarak anrezektabl ise sonucu iyileştirmek için seçilmiş hasta grubunda neoadjuvan kemoterapi verilmelidir. Cerrahi yaklaşım medyan sternotomi, clamshell insizyon veya ters T yaklaşım olabilir. Her yaklaşımın avantaj ve dezavantajları vardır. Evre III timik neoplazmalar çoğu zaman gerçek bir cerrahi tartışma konusudur ve birçok vakada neoadjuvan tedavi düşünülmelidir; ancak eğer tam cerrahi rezeksiyon yapılabilirse evre I ve II tümörlü hastalara benzer sağkalım oranları evre III'te bile elde edilebilir. Sağ atriyum ve perikard, sol brakiosefalik ven, akciğer ve diyafram rezeksiyonu yapılabilir. Tam rezeksiyon asendan aort ve ana pulmoner arter rekonstrüksiyonu veya bir frenik sinirin rezeksiyonu ile elde edilebilir. Miyokard invazyonu anrezektabilitenin açık bir belirtisidir. PolitetrafloroetilenPTFE- greftler gibi sentetik materyaller veya bovin perikard SVK rekonstrüksiyonu için sıklıkla kullanılır. Agresif multimodalite yaklaşımına rağmen 5-yılda lokal ve uzak rekürrensler görülmektedir; 5-yıllık sağkalım oranları \%46 ile \%88; 10 yıllık sağkalım \%26 ile \%84 arasında değişmektedir. Tam olmayan rezeksiyon veya basit debulking vakaları dışında tam rezeksiyon sonrası adjuvan tedavinin onaylanması için prospektif randomize çalışmalara ihtiyaç vardır.

Anahtar kelimeler: Evre III timik tümörler, cerrahi yaklaşım 
Thymoma and thymic carcinoma are the most frequent mediastinal tumors in adults. The presentation of this heterogeneous group of tumors is often completely indolent; however, they can be locally infiltrative and even metastasize outside the mediastinum. The prognosis is strictly correlated with staging, histology and completeness of surgical resection. In the past, many classifications have been suggested for staging and also the TNM system $(1,2)$ has been proposed. However, the only staging system still in use is the one developed in 1981 by Masaoka (3) and modified later by Koga in 1994 (4). Microscopic and macroscopic invasion of the capsula and involvement of adjacent organs are the key points to assess local aggressiveness and hematologic and lymphatic dissemination inside or outside the chest is reported at stage IV as for other tumors (Table I). This classification allows us to predict outcome and could be easily evaluated even at the time of surgery.

Stage III of thymic tumors represents an advanced phase of the disease with involvement of the adjacent structures: pericardium, great vessels (main pulmonary artery, ascending aorta, innominate veins and superior vena cava), phrenic nerves, lung parenchyma and chest wall. In contrast, the invasion of the mediastinal pleura requires to be confirmed histologically because the simple adhesion of the neoplasm to the serosa is staged as IIB, while direct invasion is classified as stage III. Basically, the updating of Masaoka's staging system from Haniuda (5) added a "p" status in order to provide more precise information on pleural involvement: stage IIp0, no adhesions to the mediastinal pleura; stage Ilp1, fibrous adhesions of the tumor to the pleura without invasion; stage IIp2, true pleural infiltration. However, in stage Ilp1 there is no consideration of lesion's staging: IIA or IIB.

\section{PREOPERATIVE EVALUATION}

It might be difficult to assess invasiveness preoperatively. Computed tomography (CT) could provide valuable support in identifying Masaoka stage III before surgery. Nevertheless, only surgical exploration can confirm local invasion. CT is less reliable for tumors smaller than $5 \mathrm{~cm}$ in diameter. Indirect information of local aggressiveness, such as elevation of one hemidiaphragm, is often useful. Magnetic Resonance Imaging (MRI) is an expensive tool but it is still a useful preoperative aid in evaluating neurovascular and vascular invasion (6).

Positron Emission Tomography (PET) has been evaluated as an aid for diagnosis and preoperative work up of these tumors. Although many studies sup-
Table 1. Thymoma Staging

STAGE I Macroscopically and microscopically completely encapsulated

STAGE IIA Microscopic transcapsular invasion

STAGE IIB Macroscopic invasion into the surrounding mediastinal fat tissue or grossly adherent to but not passing through the mediastinal pleura

STAGE III Invasion into the neighbouring organs

STAGE IVA Pleural or pericardial dissemination

STAGE IVB Lymphogenous or haematogenous metastases

port the use of this technique, and the SUV max could be helpful to discriminate between thymoma and thymic carcinoma, PET could not discriminate between invasive and non invasive neoplasms (7).

\section{SURGICAL CONSIDERATIONS}

Thymic tumors, those invasive and metastatic, can be cured by complete resection; in fact, this is considered nowadays the gold standard for treatment. However, a selected group of patients should receive neoadjuvant chemotherapy to improve their outcome (8-13) if the tumor is considered potentially unresectable after preoperative work up.

Thymic tumors can involve the adjacent structures and this situation could sometimes become evident only on the operating table; surgeons should be prepared to change their intraoperative strategy on demand, as well as the extent of the resection.

The gold standard approach for mediastinal neoplasms is median sternotomy; since it allows optimal exposure even in case of involvement of the adjacent structures such as the pulmonary hilum or lung parenchyma $(14,15)$. This approach carries many advantages, such as fast opening and closing, in addition to a relative reduction of postoperative pain and no sectioning of major thoracic muscles (16). In contrast, the potential risk of sternal infections and dehiscence as well as the impaired exposure of the posterior lower third of the pleural cavities and of the posterior aspect pulmonary hilum are the potential disadvantages.

Large tumors with extended involvement of both pleural cavities $(14,17)$ could be resected through a clamshell incision that consists in a combination of bilateral anterior thoracotomy with a transverse sternotomy; also tracheostomy is an indication for this access as an alternative to median sternotomy (18). In case of huge tumors bilaterally involving large seg- 
ments of the lung, this access is useful in order to provide an excellent exposure of pulmonary hili and both pleural cavities. However, notwithstanding the potential advantages, this approach should be proposed only in a selected group of patients because of the more pronounced postoperative pain and increased risks of non-infectious sternal complications such as a pseudoarthrosis and an sternal overriding $(19,20)$.

The inverse $T$ approach, an extension of the clamshell access, that has been proposed recently (21), is an combination of the traditional clamshell incision with a partial upper median sternotomy. This access is excellent for reaching both pulmonary hili and the antero-superior mediastinum, and it could be extended to the cervical region. Many clinical data have demonstrated how, in spite of the extension of the incision, the chest wall stability and the functionality of the sternocostal arch could be preserved $(21,22)$ resulting in faster recovery and an earlier respiratory rehabilitation.

With a thoracosternotomy or a hemiclamshell incision, as alternative surgical techniques, the pleural space is easily exposed. It starts with an access through the $4^{\text {th }}$ intercostal space, an anterior thoracotomy on the side with the most bulky part of the neoplasm. The approach can be completed, once the feasibility of the resection is defined, with a partial median sternotomy from the opened intercostals space upwards. The retractor used for the exposure and harvesting of the internal mammary artery for coronary artery bypass is useful for lifting the hemithorax. Phrenic nerve and brachiocephalic vessels can be better exposed through this type of incision than through standard median sternotomy, and this is extremely important in the case of larger tumors; and is also useful when upper lobectomy is to be carried out in association (23).

Stage III thymic neoplasms are often a real surgical challenge and in many cases neoadjuvant treatment should be considered. However, survival rates similar to those of patients with stage I and II tumors can be reached even at stage III if complete surgical resection is achieved (24). Resection of the right atrium and pericardium, left brachiocephalic vein, lung and diaphragm can be performed. Complete resection can be obtained by the reconstruction of the ascending aorta and main pulmonary artery or the resection of one phrenic nerve (25). Invasion of the myocardium is a clear sign of unresectability.

Resection of the anterior pericardium is not common; the exclusion of direct invasion could be difficult to ascertain due to tight adhesions between the pericardium and the tumor which can also happen in the case of a mass that appears completely capsulated. However, any adherent part of the serosa should be excised and the reconstruction of the defect is considered on a case by case basis. In the reconstruction, bovine pericardium or any other prosthetic material can be used $(26,27)$.

Lung resection should be considered only after careful evaluation of lung function. In most of the cases with limited involvement of the anterior segment of the upper lobe or the lingula, a stapled wedge resection is adequate; however, in the case of deeper invasion, lobectomy or segmentectomy should be preferred.

Pneumonectomy or extrapleural pneumonectomy is rarely performed but is preferred in invasion of pulmonary hilum or pleura.

There are many clear criteria that define phrenic nerve invasion / injury of:

1) The operation report describes phrenic nerve resection en block with the tumor;

2) The pathologic examination reports description of a phrenic nerve segment within the surgical specimen;

3) Hemidiaphragm elevation evident at postoperative chest $x$-ray was not evident before the operation (28).

The sacrifice of one phrenic nerve is not a contraindication and it does not carry any major consequence. The resection of both phrenic nerves should be avoided because it can seriously compromise lung function. In the resection of one phrenic nerve, a prophylactic diaphragm plication should be performed at the time of thymectomy (23). Bilateral involvement of the nerves from the tumor should be treated by trying to remove the neoplasm while leaving the nerves intact. Since it could result in a diaphragmatic paralysis, the impairment of the weak blood supply to the nerves should be avoided (23). More caution should be paid during these manoeuvres with patients affected by Myasthenia Gravis (MG) or in those with limited respiratory reserve.

More serious technical problems are related to vascular reconstructions. Brachiocephalic vein(s) and superior vena cava (SVC) should only be resected and reconstructed if complete resection can be obtained,. An invasion of less than $30 \%$ of the circumference of the SVC allows a partial resection of its wall and it can be repaired using a patch or through direct suture; autologous material, such as the pericardium or a venous patch, can be useful in these cases. A complete resection of the vessel with a prosthetic reconstruction should be performed in the case of a large circumferential involvement of the wall. The potential 
complications related to clamping makes these procedures a major technical challenge (29). On the other hand, partial clamping of a chronically obstructed SVC is well tolerated. In the event that complete clamping of a patent SVC must be applied, this could end in an important hemodynamic imbalance, with an increment of venous mean pressure in the cephalic region and a reduction of the arterial-venous gradient within the brain. Cerebral hemorrhage, edema and damage can be consequences; an intra-extraluminal shunt placement and a specific pharmacologic treatment may reduce this hemodynamic disorder.

The length of the conduit should be adapted to avoid tension and kinking. In the involvement of both brachiocephalic veins, the anastomosis of one of the two innominate veins with the inferior SVC stump and the closure of the contralateral one is the approach of choice The reconstruction of both veins with separate conduits leaves the patients at high risk of thrombosis and should always avoided. However, the scientific literature (15) has reported cases where a complete resection of the SVC and both innominate veins, followed by a reconstruction with a $Y$ shaped prosthesis, has been successfully performed. This procedure is preferred if neck surgery for a thyroid cancer and/or radiotherapy makes the cervical anastomoses between the two contralateral venous systems unavailable.

Synthetic materials such as polytetrafluoroethylene-PTFE-grafts or bovine pericardium are used frequently for SVC reconstruction. The presence of even and stiff edges and the rare occurrence of retraction are the advantages of the use of bovine pericardium (30). The PTFE is the most widely used among the synthetic materials due to the fact that, shortly after the implantation, it is re-epithelialized with autologous epithelial cells and this material also shows extremely favourable long term patency data.

Only the reconstruction of the left brachiocephalic vein, not of the entire SVC, is allowed by autologous venous grafts, considering its limited diameter. Suturing the vessel in a spiral fashion around an adequate support such as a syringe or a chest drainage allows creation of a saphenous vein graft with an adequate diameter (31).

Biological materials can be useful in case of patch reconstruction. The resistance to tension and pressure, adequate thickness, the fact that a separate surgical procedure for harvesting is not required, and availability even in the case of a lateral thoracotomy approach are the advantages that have made the bovine pericardium widely used. The sizing of an autologous pericardium is more difficult since it becomes shorter and tends to curl; therefore, the original method, with glutaraldehyde used for fixing the patch, has been suggested (32). This method makes tailoring much easier because it avoids shrinking and curling of the patch and allows stiff edges to be obtained. Cardio-pulmonary bypass (CPBP) should be employed only in selected cases with difficult presentations, such as intracaval-intra-atrial involvement of the SVC (33-36). In a smaller number of cases an en block resection of ascending aorta and pulmonary vessels has also been reported $(25,37,38)$. Although this approach is possible, it should be applied only in order to reach complete resection and it is considered an unfavourable long term prognostic factor (39). CPBP is required to support these procedures, also in case of necessity of reconstruction of the aortic arch (25), when even circulatory arrest and retrograde brain perfusion might be required.

\section{RESULTS}

Stage III thymic tumors might be difficult to evaluate in terms of outcome since the approach described in the literature is extremely heterogeneous., from surgery alone to the administration of induction and adjuvant chemo radiotherapy, and a combination of them $(5,8-13,24,40-44)$. Notwithstanding this aggressive multimodality approach at 5-year-local and distant recurrences are still present; 5-year survival rates range from $46 \%$ to $88 \%$; at 10 years the range is from $26 \%$ to $84 \%(24,45-47)$. The inclusion of cases undergoing partial resection and the administration of neoadjuvant and adjuvant therapy outside clinical trials and without clear indications favoured this wide variation in terms of results. At this stage, surgery is rarely performed as the only treatment. Complete resection is an important factor to achieve successful results, especially at this stage, as reported by a number of studies $(24,39,48-55)$. The R0 status and stage II tumors are the most important prognostic factor, as previously reported by a multivariate analysis in a group of 307 patients. Considering the stage irrelevant if the model included a complete resection, the study showed complete surgical resection as the only important prognostic factor (48).

According to this background, an aggressive surgical approach should be preferred and, if complete resection cannot be anticipated preoperatively, neoadjuvant therapy should be administered, since due to this treatment the survival rate can be increased 
(8-13). In the group of patient treated with a multimodality approach (neoadjuvant and adjuvant therapy) the completeness of resection loses its statistical significance (11). However, the limited number of patients in each study may lower the impact of these findings that, so far, have not been reported by other groups $(9,13)$. We can postulate that the goal of complete tumoral clearance in this setting is achieved thanks to the combined modality treatment that makes the resection less crucial (11). Also, in order to allow the complete clearance of the bed of the tumor, postoperative radiotherapy over the anterior mediastinum shows greater efficacy after an induction therapy and in association with adjuvant chemotherapy. Thanks to this observation, the GETT classification could have more weight revising the staging system, even if it plays a significant role only preoperatively.

The role of surgery in management of thymic tumors has been recently evaluated in a systematic review (56). A literature search on publications in English between 1981 and 2007 formed the basis of that study. A prospective randomized controlled trial and 23 retrospective series with between 40 and 1093 patients represent the final analysis and all patients included in these studies underwent different combinations of surgery, chemo and radiotherapy. According to that review, these are the evidencebased conclusions for stage III thymoma treatment:

- A complete resection of stage III thymomas should be attempted by the surgeon in order to increase survival (C1: methods weak; effects clear);

- A subtotal resection associated with an adjuvant therapy could be applied believing that they will increase survival (C2: methods weak; effects equivocal);

- Median sternotomy should be the preferred access for the surgery of stage II thymomas since it permits better exposure of the neoplasms and is extremely helpful for intraoperative macroscopic staging (C2: methods weak; effect clear).

In conclusion, surgery still plays a significant role in the treatment of stage III thymic neoplasms and is the first choice where complete resection can be anticipated during preoperative work up. A complete resection could be eventually achieved in the case of invasive neoplasms after induction chemotherapy; the latter can be helpful in reducing the volume of the mass and obtaining downstaging. Adjuvant treatment after complete resection needs validation through prospective randomized trials, except in the case of incomplete resection or simple debulking where this therapy is clearly recommended.

\section{REFERENCES}

1. Yamakawa $\mathrm{Y}$, Masaoka A, Hoshimoto $\mathrm{T}$, et Al. A tentative tumor - node metastasis classification of thymoma. Cancer 1991;68:1984-7. [CrossRef]

2. International Union Against Cancer. TNM supplement. A commentary on uniform use. 2003; 3rd Ed. Wiley - Liss. New York.

3. Masaoka A, Monden Y, Nakahara K, Tanioka T. Follow up study of thymomas with special reference to their clinical stages. Cancer 1981;48:2485-92. [CrossRef]

4. Kpgs $\mathrm{K}$, Matsuno $\mathrm{Y}$, Noguchi $\mathrm{M}$, et al. A review of 78 thymomas: modification of staging system and reappraisal of conventional division into invasive and non invasive thymoma. Pathol Int 1994;44:359-67.

5. Haniuda $M$, Morimoto $M$, Nishimura $H$, et al. Adjuvant radiotherapy after complete resection of thymoma. Ann Thorac Surg 1992;54:311-5. [CrossRef]

6. Rosado-de-Christenson ML, Strollo DC, Marom EM. Imaging of thymic epithelial neoplasms. Hematol Oncol Clin North Am 2008;22:409-31. [CrossRef]

7. Puri V, Meyers BF. Utility of positron emission tomography in the mediastinum: moving beyond lung and esophageal cancer staging. Thorac Surg Clin 2009;19:7-15. [CrossRef]

8. Venuta F, Rendina EA, Pescarmona E, et al. Multimodality treatment of thymoma: a prospective study. Ann Thorac Surg 1997;64:1585-92. [CrossRef]

9. Venuta $F$, Rendina EA, Longo F, et al. Long term out come after multimodality treatment for stage III thymic tumors. Ann Thorac Surg 2003;76:1866-72. [CrossRef]

10. Rea F, Sartori F, Loy M, et Al. Chemotherapy and operation for invasive thymoma. J Thorac Cardiovasc Surg 1993;106:543-9.

11. Lucchi M, Ambrogi MC, Duranti L, et al. Advanced stage thymomas and thymic carcinomas: results of multimodality treatments. Ann Thorac Surg 2005;79:1840-4. [CrossRef]

12. Macchiarini $P$, Chella A, Ducci $F$, et al. Neoadjuvant chemotherapy, surgery and postoperative radiation therapy for invasive thymoma. Cancer 1991;68:706-13. [CrossRef]

13. Kim ES, Putnam JB, Komaki R, et al. Phase II study of a multidisciplinary approach with induction chemotherapy followed by surgical resection, radiation therapy and consolidation chemotherapy for unresectable malignant thymomas: final report. Lung Cancer 2004;44:369-79. [CrossRef]

14. Bacha EA, Chapelier AR, Macchiarini P, et Al. Surgery for invasive primary mediastinal tumors. Ann Thorac Surg 1998;66:234-8. [CrossRef]

15. Chen KN, Xu SF, Gu ZD, et Al. Surgical treatment of complex malignant anterior mediastinal tumors invading the superior vena cava. World J Surg 2006;30:162-70. [CrossRef]

16. Cooper JD, Nelems JM, Pearson FG. Extended indications for median sternotomy in patients requiring pulmonary resection. Ann Thorac Surg 1978;26:413-20. [CrossRef]

17. Bains MS, Ginsberg RJ, Jones WG 2nd, et al. The clamshell incision: an improved approach to bilateral pulmonary and mediastinal tumor. Ann Thorac Surg 1994;58:30-3. [CrossRef]

18. Marshall WG Jr, Meng RL, Ehrenhaft JL. Coronary artery bypass grafting in patients with a tracheostoma: use of a bilateral thoracotomy incision. Ann Thorac Surg 1988;46:465-6. [CrossRef] 
19. Wright C. Transverse sternothoracotomy. Chest Surg Clin N Am 1996;6:149-56.

20. Brown RP, Esmore DS, Lawson C. Improved sternal fixation in the transsternal bilateral thoracotomy incision. J Thorac Cardiovasc Surg 1996;112:137-41. [CrossRef]

21. Marta GM, Aigner C, Klepetko W. Inverse T incision provides improved accessibility to the upper mediastinum. J Thorac Cardiovasc Surg 2005;129:221-3. [CrossRef]

22. Aigner C, Hoda MAR, Klepetko W. Combined cervicothoracic approaches for complex mediastinal masses. Thorac Surg Clin 2009;19:107-12. [CrossRef]

23. Kaiser LR. Surgical treatment of thymic epithelial neoplasms. Hematol Oncol Clin N Am 2008;22:175-88. [CrossRef]

24. Nakahara K, Ohno K, Hashimoto J, et al. Thymoma: results with complete resection and adjuvant postoperative irradiation in 141 consecutive patients. J Thorac Cardiovasc Surg 1988;95:1041-7.

25. Fujino S, Teruke N, Watorida S, et al. Reconstruction of the aortic arch in invasive thymoma under retrograde cerebral perfusion. Ann Thorac Surg 1998;66:263-4. [CrossRef]

26. Pace Napoleone C, Oppido G, Angeli E, Gargiulo G. Resternotomy in pediatric cardiac surgery: CoSeal initial experience. Interact Cardiovasc Thorac Surg 2007;6:21-3 [CrossRef].

27. Pace Napoleone C, Valori A, Crupi G, et al. An observational study of CoSeal for the prevention of adhesions in pediatric cardiac surgery. Interact Cardiovasc Thorac Surg 2009;9:979-82.

28. Salati M, Cardillo G, Carbone L, et al. latrogenic phrenic nerve injury during thymectomy: the extent of the problem. J Thorac Cardiovasc Surg 2010;139:77-8. [CrossRef]

29. Gonzalez-Fajardo JA, Garcia-Yuste M, Florez S, et al. Hemodynamic cerebral repercussions arising from surgical interruption of the superior vena cava. Experimental model. J Thorac Cardiovasc Surg 1994;107:1044-9.

30. D'Andrilli A, Ciccone AM, Ibrahim M, et al. A new technique for prosthetic reconstruction of the superior vena cava. J Thorac Cardiovasc Surg 2006;132:192-4. [CrossRef]

31. Doty DB. Bypass of superior vena cava: Six years' experience with spiral vein graft for obstruction of superior vena cava due to benign and malignant disease. J Thorac Cardiovasc Surg 1982;83:326-9.

32. D'Andrilli A, Ibrahim M, Venuta F, et al. Glutaraldehide preserved autologous pericardium for patch reconstruction of the pulmonary artery and superior vena cava. Ann Thorac Surg 2005;80:357-8. [CrossRef]

33. Minato N, Rikitake K, Ohnishi $\mathrm{H}$, et al. Invasive thymoma with intracaval growth extending and directly invading the right atrium. J Cardiovasc Surg (Torino) 1999;40:915-7.

34. De Giacomo T, Mazzesi G, Venuta F, Coloni GF. Extended operation for recurrent thymic carcinoma presentino with intracaval growth and intracardiac extension. J Thorac Cardiovasc Surg 2007;134:1364-5. [CrossRef]

35. Kostantinov IE, Saxena P, Koniszko M, et al. Superior vena cava obstruction by tumor thrombus in invasive thymoma: diagnosis and surgical management. Heart Lung Circ 2007;16:462-4. [CrossRef]

36. Amirghogran $A A$, Ememinia $A$, Rayatpisheh $S$, et al. Intracardiac invasive thymoma presenting as superior vena cava syndrome. Ann Thorac Surg 2009;87:1616-8. [CrossRef]

37. Tseng YL, Wang ST, Wu MH, et al. Thymic carcinoma: involvement of great vessels indicates poor prognosis. Ann Thorac Surg 2003;76:1041-5. [CrossRef]
38. Park BJ, Bacchetta M, Mains MS, et al. Surgical management of thoracic malignancies invading the heart or great vessels. Ann Thorac Surg 2004;78:1024-30. [CrossRef]

39. Okumura M, Miyoshi S, Takeuchi $\mathrm{Y}$, et al. Results of surgical treatment of thymomas with special reference to the involved organs. J Thorac Cardiovasc Surg 1999;117:605-11. [CrossRef]

40. Urgesi A, Monetti U, Rossi $G$, et al. Role of radiation therapy in locally advanced thymoma. Radiother Oncol 1990;19:273-80. [CrossRef]

41. Jackson MA, Mall DL. Postoperative radiotherapy in invasive thymoma. Radiother Oncol 1991;21:77-82. [CrossRef]

42. Latz D, Schraube P, Oppiz U, et al. Invasive thymoma: treatment with postoperative radiation therapy. Radiology 1997;204:859-64.

43. Gripp S, Hilgers K, Wurm R, Schmitt G. Thymoma: prognostic factors and treatment outcomes. Cancer 1988;83:1495-503. [CrossRef]

44. Ogawa K, Uno T, Toita T, et al. Postoperative radiotherapy for patients with completely resected thymoma: a multiinstitutional, retrospective review of 103 patients. Cancer 2002;94:1405-13. [CrossRef]

45. Elert O, Buchwald J, Wolf K. Epithelial thymic tumors - therapy and prognosis. Thorac Cardiovasc Surg 1988;36:109-13. [CrossRef]

46. Blumberg D, Burt ME, Bains MS, et al. Thymic carcinoma: current staging does not predict prognosis. J Thorac Cardiovasc Surg 1998;115:303-9. [CrossRef]

47. Strobel P, Bauer A, Puppe B, et al. Tumor recurrence and survival in patients treated for thymomas and thymic squamous cell carcinomas: a retrospective analysis. J Clin Oncol 2004;22:1501-9. [CrossRef]

48. Regnard JF, Magdeleinat P, Dromer C, et al. Prognostic factors and long term results after thymoma resection. A series of 307 patients. J Thorac Cardiovasc Surg 1996;112:376-84. [CrossRef]

49. Lewis JE, Wick MR, Scheithaner BW, et al. Thymoma. A clinicopathologic review. Cancer 1987;60:2727-43. [CrossRef]

50. Maggi G, Casadio C, Cavallo A, et al. Thymoma: results of 241 operated cases. Ann Thorac Surg 1991;51:152-6. [CrossRef]

51. Okumura M, Ohta M, Tateyama H, et al. The World Health Organization histologic classification system reflects the oncologic behaviour of thymoma: a clinical study of 273 patients. Cancer 2002;94:624-32. [CrossRef]

52. Wilkins KB, Sheikh E, Green R, et al. Clinical and pathologic predictors of survival in patients with thymoma. Ann Surg 1999;230:562-74. [CrossRef]

53. Blumberg D, Port JL, Wechsler B, et al. Thymoma: a multivariate analysis of factors predicting survival. Ann Thorac Surg 1995;60:908-14. [CrossRef]

54. Rea F, Marulli G, Girardi R, et al. Long-term survival and prognostic factors in thymic epithelial tumours. Eur $\mathrm{J}$ Cardiothorac Surg 2004;26:412-8. [CrossRef]

55. Myojin M, Choi NC, Wright CD, et al. Stage III thymoma: pattern of failure after surgery and postoperative radiotherapy and its implication for future study. Int $\mathrm{J}$ Radiat Oncol Biol Phys 2000;46:927-33. [CrossRef]

56. Davenport E, Malthaner RA. The role of surgery in the management of thymoma: a systematic review. Ann Thorac Surg 2008;86:673-84. [CrossRef] 